\title{
PERANCANGAN SISTEM INFORMASI DENGAN METODE ENTERPRISE RESOURCE PLANNING (ERP) UNTUK MANAJEMEN DAN INVENTORI PADA APOTEK KHARISMA FARMA DENPASAR
}

\author{
Vincensia Lusi Kurniawan ${ }^{1)}$ Christian Tonyjanto ${ }^{2)}$ Aulia Iefan Datya ${ }^{3)}$ \\ Program Studi Sistem Informasi 1) 2) 3) \\ Fakultas Ilmu Kesehatan Sains dan Teknologi, Universitas Dhyana Pura, badung, Bali 1) 2) 3) \\ vincensialusi@gmail.com ${ }^{1)}$ christiantonyjanto@undhirabali.ac.id ${ }^{2}$ iefandatya@undhirabali.ac.id ${ }^{3)}$
}

\begin{abstract}
Enterprise Resource Planning (ERP) is very important for organization management especially for information systems. So it can produce for the correct and accurate data. Inventory management of Apotek Kharisma Farma Denpasar is still working manually the result of it organizing inventory, report and transaction have not been neatly arranged. Information system management and inventory of Apotek Kharisma Farma Denpasar use Enterprise Resource Planning (ERP) methode with waterfall design. All of data in information system Apotek Kharisma Farma Denpasar have an effection decision making by management in Apotek Kharisma Farma. Manual data converted into database such as data of medicine inventory, salestransaction, purchase transaction, medicine, sales and purchase report process, so information system of this Apotek is expected to support Apotek operations in a predetermined aspects. This information system design of Apotek Kharisma Farma Denpasar is expected can repair Apotek management and inventory with features which are already designed and easy to use.
\end{abstract}

Keywords: Enterprise Resource Planning (ERP), waterfall methode, databse, management system

\begin{abstract}
ABSTRAK
Enterprise Resource Planning (ERP) sangat berperan penting dalam manajemen organisasi khususnya dibidang sistem informasi, sehingga dapat menghasilkan data yang tepat dan akurat. Manajemen inventaris di Apotek Kharisma Farma Denpasar masih dikerjakan secara manual sehingga pengorganisasian inventaris, laporan dan transaksi belum tersusun secara rapi. Sistem Informasi manajemen dan inventaris pada Apotek Kharisma Farma Denpasar menggunakan metode Enterprise Resource Planning (ERP) dengan rancangan waterfall. Seluruh data yang terdapat di sistem informasi Apotek Kharisma Farma berpengaruh pada pengambilan keputusan oleh pihak manajemen dalam pengelolaan Apotek Kharisma Farma. Data - data manual yang dikonversikan ke dalam database antara lain: data inventaris obat, transaksi penjualan, transaksi pembelian, laporan obat, penjualan dan pembelian. Kemampuan Sumber Daya Manusia (SDM) dapat mempengaruhi setiap proses transaksi dan laporan sehingga sistem informasi Apotek ini diharapkan dapat mendukung operasional apotek dalam aspek - aspek yang sudah ditentukan. Dari perancangan sistem informasi Apotek Kharisma Farma Denpasar diharapkan dapat memperbaiki manajemen pengelolaan apotek dan inventaris dengan fitur - fitur yang sudah dirancangan dan mudah digunakan.
\end{abstract}

Kata kunci: Enterprise Resource Planning (ERP), metode waterfall, basis data, sistem manajemen 


\section{PENDAHULUAN}

Perkembangan teknologi informasi komunikasi telah berkembang cepat di berbagai bidang seperti pendidikan pariwisata maupun kesehatan, serta untuk menyesuaikan diri dengan perkembangan teknologi agar tidak tertinggal dengan bidang atau perusahaan lain dalam pelayanan kepada masyarakat. Perkembangan perusahaan diberbagai bidang usaha mulai berbenah diri untuk memenangkan persaingan yang semakin berat, peran teknologi informasi sangatlah penting dalam mengembangkan usaha diberbagai bidang agar usaha yang telah dibangun bertambah maju dan tidak kalah saing dengan perusahaan lain. Selain ditunjang dengan peran teknologi informasi dibidang peralatan, juga harus ditunjang dengan sistem manajemen, aplikasi dan pengguna yang kompeten dalam menangani permasalahan - permasalahan yang timbul dalam perusahaan.

Semakin meningkatnya kebutuhan informasi dan peranan sistem yang harus berkembang maka dibutuhkan suatu sistem manajemen yang baik. Sistem manajemen juga menyangkut adanya suatu database yang mampu mengorganisasikan data yang ada di dalamnya secara akurat dan mampu mengatasi relasi antar data sehingga informasi berdaya guna dan berpengaruh pada proses pengambilan keputusan pihak manajemen perusahaan. Kekurangan persediaan obat dapat terhentinya proses transaksi dan suatu ketika bisa mengalami kehabisan stok obat hal ini dapat terjadi bila perusahaan tersebut tidak memiliki persediaan obat yang mencukupi. Biaya persediaan obat darurat tentunya jauh lebih mahal, sebaliknya jika perusahaan memiliki persediaan obat yang cukup besar perusahaan dapat memenuhi permintaan pelanggan, namun persediaan obat yang terlalu besar (over stock) dapat berakibat terlalu tingginya beban biaya guna menyimpan dan memelihara obat tersebut selama penyimpanan digudang.

Apotek Kharisma Farma adalah sebuah perusahaan dagang yang menjual obat, baik dengan resep dokter ataupun tidak. Masalah yang dihadapi apotek saat ini adalah sulitnya mendapatkan informasi yang akurat dan cepat tentang persediaan barang di gudang dan dalam pendataan obat yang dilakukan satu per satu. Terjadinya kelalaian dalam proses pemesanan obat sehingga mengakibatkan persediaan obat yang terlalu besar, yang membutuhkan waktu dalam pencarian data dan pengecekan data obat untuk keperluan pemeriksaan kembali. Pada sistem yang sedang berjalan pada apotek saat ini, transaksi penjualan kepada pelanggan dicatat kedalam nota dan pembukuan akan tetapi tidak semua obat yang terjual tercatat kedalam nota. Hal ini menyebabkan data penjualan menjadi tidak akurat karena nota tersebut akan dicatat ke dalam buku transaksi penjualan. Dengan adanya pencatatan nota yang tidak lengkap di dalam buku transaksi penjualan maka menyebabkan terjadinya pembuatan laporan data penjualan yang tidak sesuai dengan data obat yang keluar. Sedangkan transaksi pembelian obat pada supplier masih berupa faktur - faktur pembelian serta tidak adanya pencatatan secara detail tentang masa kadaluarsa obat. Inilah yang menyebabkan apotek sulit untuk mengetahui informasi persediaan obat dengan akurat dan cepat, dalam proses pengecekan stok fisik di gudang hanya dilakukan satu bulan sekali. Hal lain yang menjadi masalah dari tidak akurat dan cepatnya informasi ini akan menyulitkan apotek dalam mengambil keputusan secara cepat pergerakan barang mana yang sifatnya laku (fast moving) dan tidak laku (slow moving). Dan sering terjadinya kesalahan dalam pembuatan laporan persediaan obat, penjualan obat dan pembelian obat yang disebabkan kurangnya pegawai dalam memahami cara pembuatan laporan dan manajemen sistem yang kurang maksimal.

Dengan latar belakang di atas penulis mencoba membuat suatu perancangan sistem informasi mengenai manajemen dan inventori obat. Maka dengan demikian penulis mencoba mengangkat judul "Perancangan Sistem Informasi dengan Metode Enterprise Resource Planning (ERP) untuk Manajemen dan Inventory Pada Apotek Kharisma Farma Denpasar" yang diharapkan bisa memberikan informasi mengenai manajemen serta inventori obat kepada admin, kasir dan pimpinan sehingga dapat melihat perkembangan kemajuan apotek kharisma farma.

\section{TINJAUAN PUSTAKA \\ Pengertian Manajemen}

Manajemen adalah sebuah proses yang dilakukan untuk menwujudkan tujuan organisasi melalui rangkaian kegiatan berupa perencanaan, pengorganisasian, pengarahan, dan pengendalian orang - orang serta sumber daya orgnisasi lainnya. Berdasarkan pengertian diatas, maka dapat disimpulkan bahwa manajemen pada dasarnya merupakan seni atau proses dalam menyelesaikan sesuatu yang terkait dengan pencapaian tujuan. Dalam penyelesaian akan sesuatu tersebut, terdapat tiga faktor yang terlibat: 
- Adanya penggunaan sumber daya organisasi, baik sumber daya manusia, maupun faktor - faktor produksi lainnya. Atau sebagaimana menurut Griffin, sumber daya tersebut meliputi sumber daya manusia, sumber daya alam, sumber daya keuangan, serta informasi.

- Adanya proses yang bertahap dari mulai perencanaan, pengorganisasian, pengarahan, dan pengimplementasian, hingga pengendalian dan pengawasan.

- Adanya seni dalam menyelesaikan pekerjaan.

\section{Sistem Informasi Manajemen}

Sistem Informasi Manajemen (SIM) atau Management Information System (MIS) adalah sistem informasi yang digunakan untuk menyajikan informasi yang digunakan untuk mendukung operasi, manajemen, dan pengambilan keputusan dalam suatu organisasi.Biasanya, SIM menghasilkan informasi untuk memantau kinerja, memelihara koordinasi, dan menyediakan informasi untuk operasi organisasi.Umumnya, SIM mengambil data dari sistem pemrosesan transaksi .

\section{Apotek}

Apotek merupakan suatu tempat pelayanan produk maupun jasa kefarmasian (obat - obatan) kepada masyarakat. Pelayanan kefarmasian adalah suatu pelayanan langsung dan bertanggung jawab kepada pasien yang berkaitan dengan sediaan farmasi dengan maksud mencapai hasil yang pasti untuk meningkatkan mutu kehidupan pasien. Pekerjaan kefarmasian yang dilakukan meliputi pembuatan termasuk pengendalian mutu sediaan farmasi, pengamanan, pengadaan, penyimpanan, dan pendistribusian atau penyaluran obat, pengelolaan obat, pelayanan obat atas resep dokter, pelayanan informasi obat, serta pengembangan obat, bahan obat, obat tradisional dan kosmetika.

\section{Inventory}

inventori (persediaan) adalah bahan baku, produk setengah jadi, produk jadi yang berada di dalam sistem produksi pada suatu waktu, yang bersifat sebagai buffer (penyangga) yang belum digunakan (idle) yang mempunyai nilai ekonomis di masa mendatang pada saat aktif.

Fungsi dari manajemen inventori:

- Perencanaan inventori: menentukan kebutuhan material untuk memenuhi kebutuhan sesuai rencana operasi dan produksi yang telah disusun, yaitu berapa banyak yang harus dipesan.

- Pengendalian inventori: menentukan tingkat inventori yang sesuai dimana pemesanan harus dilakukan kembali, persediaan pengaman, dan kondisi inventory tersebut yang terkait.

\section{Framework Codeigniter}

Codeigniter merupakan framework PHP yang diklain memliki eksekusi tercepat dibandingkan dengan framework lainnya. Framework Codeigniter ini bersifat open source sehingga pengembang dapat mengurangi jumlah baris dalam kode dan dapat meminimalisasi kesalahan penulisan kode perintah dan bugs, mengurangi ukuran file, serta mempercepat eksekusi. Codeigniter bekerja berdasarkan konsep dasar MVC, MVC (model view controller) merupakan sebuah pattern teknik pemrograman yang memisahkan bisnic logic (alur pikir), data logic (penyimpanan data), dan presentasi logic (antarmuka aplikasi) atau secara sederhana adalah memisahkan antara desain, data dan proses.

\section{JQuery}

JQuery adalah suatu library (framework) javascript yang menekankan bagaimana interkasi antara javascript dengan HTML. JQuery mempermudah dan mempercepat developer web dalam membuat kode javascript. Secara standar, apabila seseorang membuat kode javascript, maka diperlukan kode yang cukup panjang, bahkan terkadang sangat sulit dipahami. Disinilah peranan JQuery sebagai javascript Library, dimana pengembang web dapat langsung memanggil fungsi yang terdapat di dalam Library tersebut.

File JQuery hanya satu dan ukurannya kecil sehingga cepat aksesnya, fitur JQuery paling lengkap dibandingkan dengan framework javascript yang lain, JQuery dapat bekerja di berbagai web browser, seperti Mozilla Firefox, Internet Explorer, Google Chrome, Opera dan browser lainnya. JQuery open source, sehingga dapat dimodifikasi sesuai kebutuhan.

\section{PHP}

PHP (PHP Hypertext Prepocessor) adalah bahasa scripting server - side bagi pemrograman web.Secara sederhana, PHP merupakan tool bagi pengembangan web dinamis. PHP sangat popular karena memiliki 
fungsi built - in lengkap, cepat, mudah dipelajari, dan bersifat gratis. Skrip PHP cukup disisipkan pada kode HTML agar dapat bekerja.PHP dapa berjalan di berbagai web server dan sistem operasi yang berbeda

\section{System Development Life Cycle (SDLC)}

Pengembangan sistem informasi yang berbasis komputer dapat merupakan tugas kompleks yang membutuhkan banyak sumber daya dan dapat memakan waktu berbulan bulan bahkan bertahun - tahun untuk menyelesaikannya. Proses pengembangan sistem melewati beberapa tahapan dari mulai sistem itu direncanakan sampai dengan sistem tersebut diterapkan, dioperasikan dan dipelihara. Bila operasi sistem yang sudah dikembangkan masih timbul kembali permasalahan - permasalahan yang kritis serta tidak dapat diatasi dalam tahap pemeliharaan sistem, maka perlu dikembangkan kembali suatu sistem untuk mengatasinya dan proses ini kembali ke tahap yang pertama, yaitu tahap perencanaan sistem. Siklus ini disebut dengan siklus hidup suatu sistem (systems life cycle). Daur atau siklus hidup dari pengembangan sistem merupakan suatu bentuk yang digunakan untuk menggambarkan tahapan utama dan langkah - langkah di dalam tahapan tersebut dalam proses pengembangannya.

\section{Pengembangan Sistem Dengan Waterfall}

Dalam perancangan aplikasi ini penulis menggunakan metode Waterfall. Metode Waterfall adalah metode yang menyarankan sebuah pendekatan yang sistematis dan sekuensial melalui tahapan tahapan yang ada pada SDLC untuk membangun sebuah perangkat lunak. Gambar menjelaskan bahwa metode Waterfall menekankan pada sebuah keterurutan dalam proses pengembangan perangkat lunak. Metode ini adalah sebuah metode yang tepat untuk membangun sebuah perangkat lunak yang tidak terlalu besar dan sumber daya manusia yang terlibat dalam jumlah yang terbatas.a bagian tersebut ada pada gambar 1 sebagai berikut:

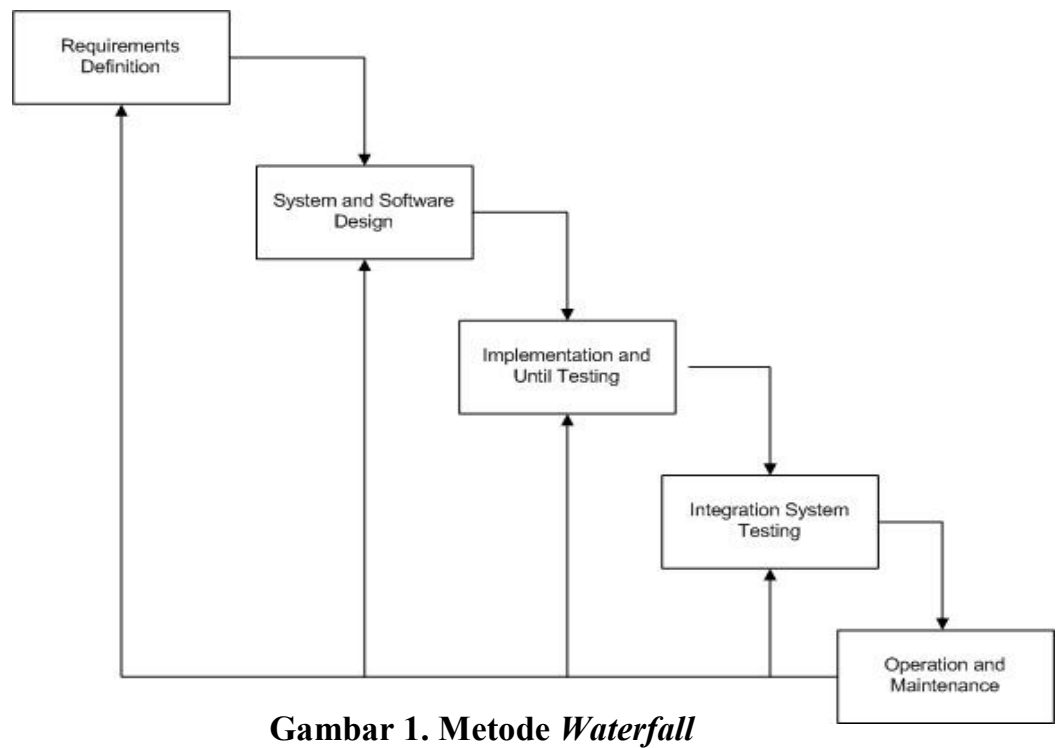

\section{Enterprise Resource Planning (ERP)}

Enterprise Resource Planning (ERP) merupakan sebuah framework transaksi enterprise yang menghubungkan proses pemesanan barang, manajemen inventarisasi dan kontrol, perencanaan distribusi dan produksi, dan keuangan. ERP bekerja sebagai kekuatan lintas fungsional perusahaan yang mengintegrasikan dan mengautomatisasi berbagai proses bisnis internal dan sistem informasi termasuk manufacturing, logistik, distribusi, akuntansi, keuangan, dan sumber daya manusia dari sebuah perusahaan.

Sistem ERP mencatat arus sumber daya bisnis (seperti uang bahan mentah, dan kapasitas produksi), dan status dari perjanjian yang dibuat dalam proses bisnis (seperti pesanan pelanggan, pesanan pembelian, dan gaji pegawai), tidak peduli departemen mana (manufacturing, penjualan, akunting, dsb) yang memasukkan data ke dalam sistem. Konsep 
utama ERP dapat digambarkan dalam satu diagram seperti dibawah ini gambar 2.

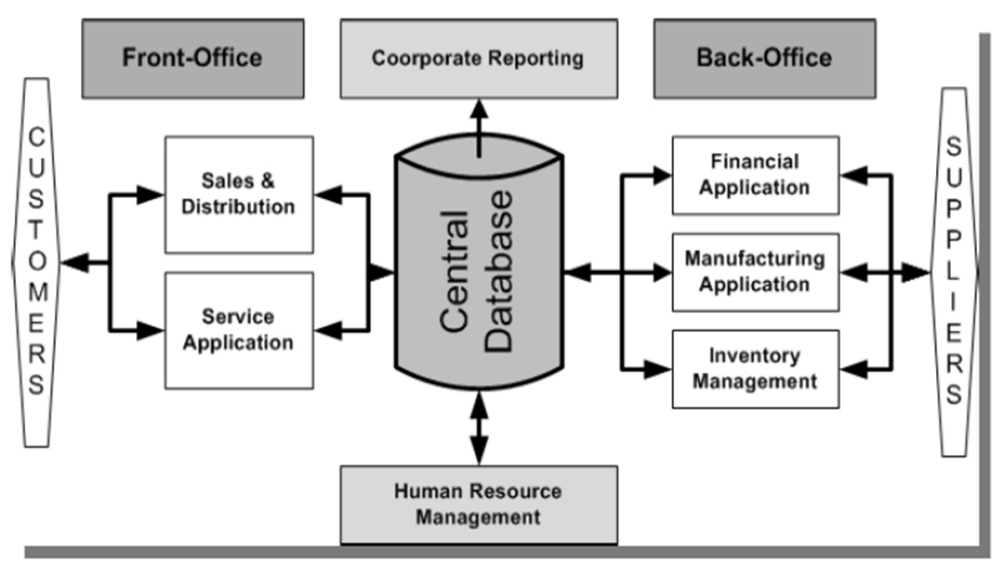

Gambar 2. Konsep Dasar ERP

Implementasi

\section{METODELOGI PENELITIAN}

\section{Studi Kepustakaan}

Dalam menunjang penelitian akan dilakukan studi pustaka dengan mempelajari beberapa buku teks, jurnal, dan situs lainnya yang menunjang beberapa penelitian tentang perancangan sistem informasi dengan metode enterprise resource planning (ERP) untuk manajemen dan inventori.

\section{Analisis dan Perancangan Sistem}

Perancangan sistem aplikasi ini menggunakan metode System Development Life Cycle (siklus hidup pengembangan sistem. SDLC adalah keseluruhan proses dalam membangun sistem informasi melalui beberapa langkah. Ada beberapa model SDLC. Dalam perancangan sistem memakai model SDLC waterfall yang cukup popular dan banyak digunakan seperti Feasibility study, Alokasi waktu, Cakupan (scope), pengumpulan data, proses perancangan sistem, dan disain input serta output.
Tahap ini dilakukan rancang bangun sistem ke dalam suatu perangkat lunak dari model yang telah di rancang pada tahap sebelumnya. aplikasi system informasi manajemen dan inventori metode enterprise resource planning dengan Web Server: Xampp v1.8.3 for windows

\section{Data Flow Diagram}

Data flow diagram digunakan untuk menggambarkan perancangan sistem ini dari proses - proses yang berhubungan datu sama lain. Bagian ini akan menjelaskan data flow diagram perancangan sistem manajemen inventori apotek.

\section{Context Diagram}

Diagram konteks merupakan penggambaran prosedur program dari perancangan sistem manajemen ini secara umum dari keseluruhan sistem yang ada. Pada diagram konteks digambarkan sumber serta tujuan data yang akan diproses. Gambar 3 merupakan diagram konteks dari perancangan sistem manajemen inventori apotek.

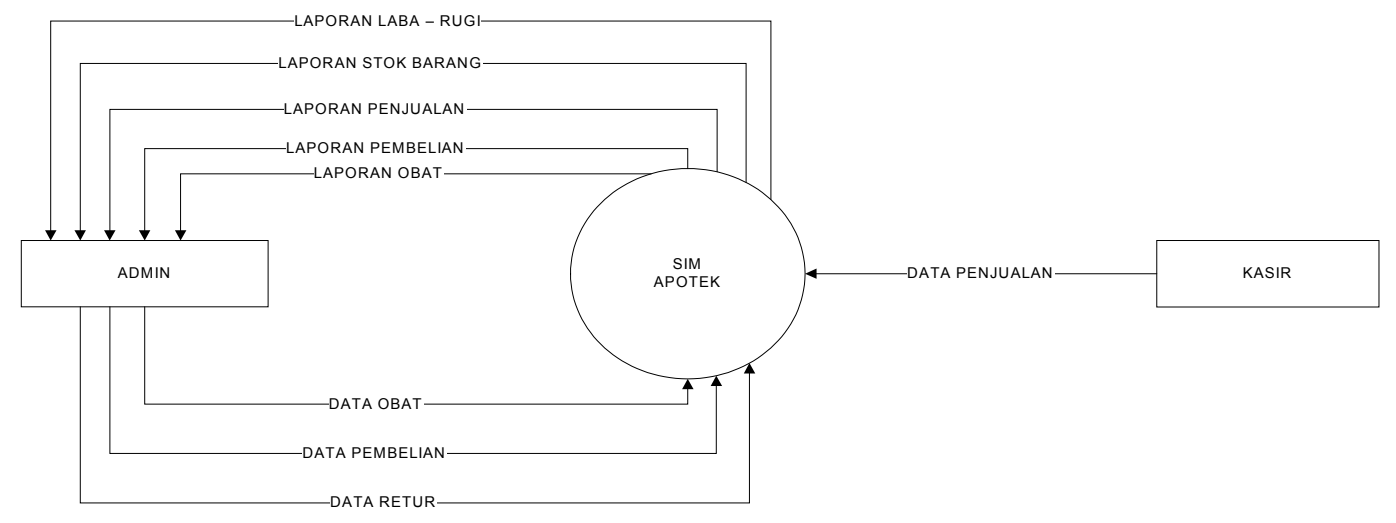




\section{Data Flow Diagram}

Data flow diagram merupakan penggambaran yang lebih spesifik dan kompleks dari diagram konteks diatas. Pada data flow diagram akan terlihat lebih jelas fungsi setiap masing - masing subyek. Gambar 4 merupakan data flow diagram dari perancangan sistem manajemen inventori apotek.

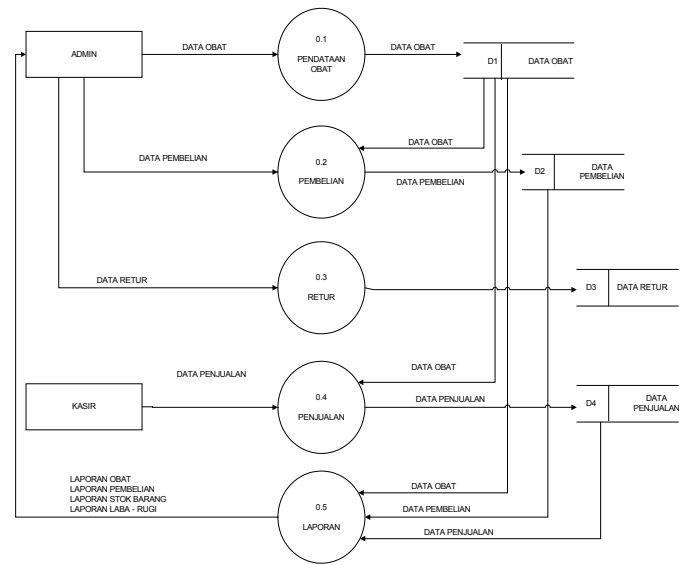

Gambar 4. Data Flow Diagram

\section{HASIL DAN PEMBAHASAN}

\section{Kebutuhan Sistem}

Sistem informasi manajemen dan inventori pada apotek kharisma farma denpasar dapat dijalankan pada sebuah perangkat keras (hardware) dan perangkat lunak (software) dengan spesifikasi sebagai berikut: (1) Processor AMD A10 Quad - Core, RAM 2GB, Harddisk 500GB, VGA 1GB, Mouse, Printer (2)Web Server: Xampp v1.8.3 for windows, Desain dan Script Editor: Macromedia Dreamweaver 8, Browser: Google Chrome 15.0.8 forn windows, Sistem Operasi: Windows 864 bit.

\section{Entity Relationship Diagram}

Entity Relationship Diagram (ERD) menggambarkan bagaimana hubungan antara setiap entitas yang terkait pada kegiatan pembelian obat, penjualan obat, stok obat, dan laporan setiap bulannya. Seperti gambar dibawah ini:

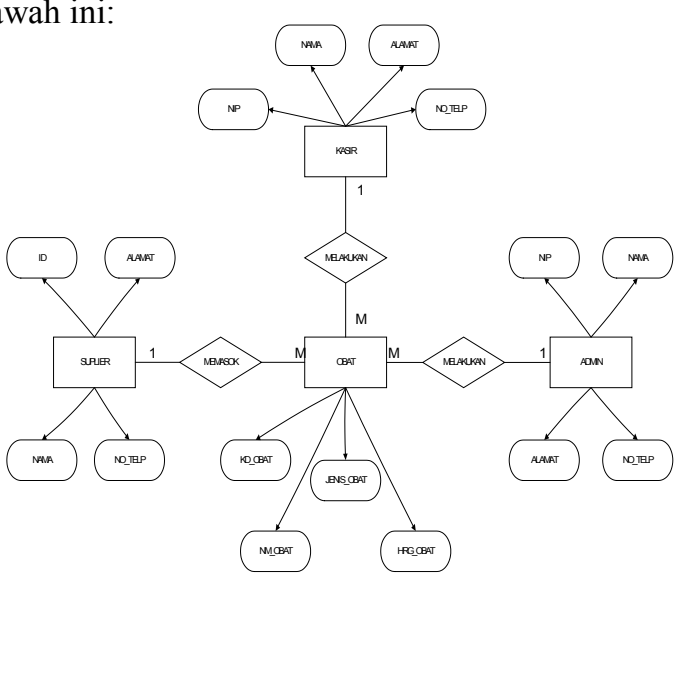

Gambar 5. ERD

\section{Implementasi}

Menu Utama Sistem Informasi Manajemen dan Inventori dengan Metode ERP yang ada di halaman menu utama (Home), menu Master, Menu Transaksi, Menu Laporan dan Menu Keluar.

\section{Halaman Home}

Tampilan halaman login user dengan hak akses admin dan kasir, admin dapat memasukkan username dan password yang telah terdaftar untuk masuk ke menu utama.

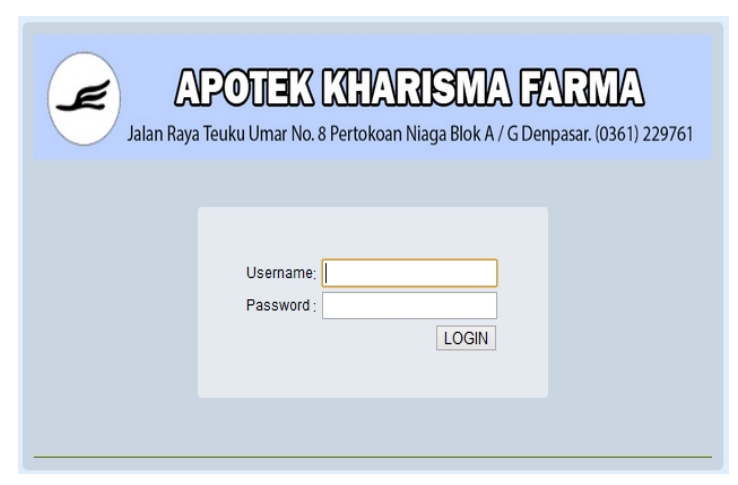

Gambar 6. Menu Home 


\section{Menu Form Barang}

Form barang adalah halaman admin yang dapat melihat data - data barang, menginput, menghapus dan mengedit data barang

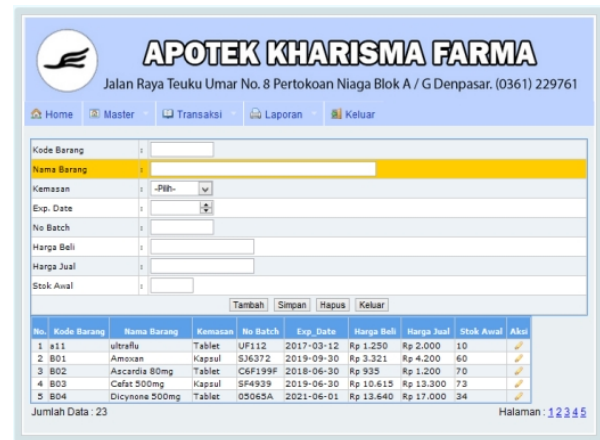

Gambar 7 Menu Form Barang

\section{Menu Transaksi Pembelian}

Transaksi pembelian ini dapat diakses oleh user "admin" yang melakukan transaksi pembelian obat antara bagian admin apotek dengan bagian supplier dalam pemesanan obat yang kemudian dimasukkan dalam sistem.

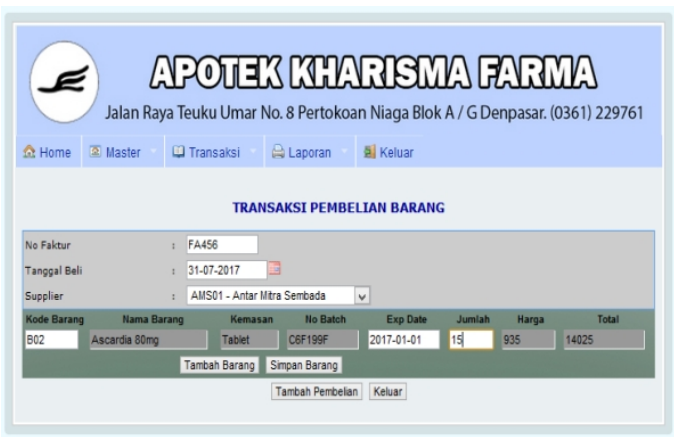

\section{Gambar 8 Menu Transaksi Pembelian}

\section{Menu Transaksi Penjualan}

Menu transaksi penjualan ini hanya dapat diakses oleh pengguna "user" atau "kasir" yang telah di daftar sebelumnya oleh admin untuk dapat berinteraksi antara kasir dengan customer yang akan membeli obat.

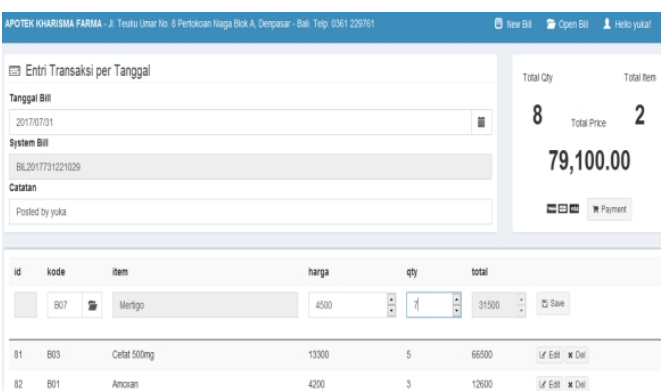

Gambar 9 Menu Transaksi Penjualan

\section{Menu Retur}

Transaksi retur ini mengenai obat yang telah rusak atau kadaluarsa dengan kriteria 3 bulan sebelum tanggal kadaluarsa sehingga dapat dikembalikan kepada supplier

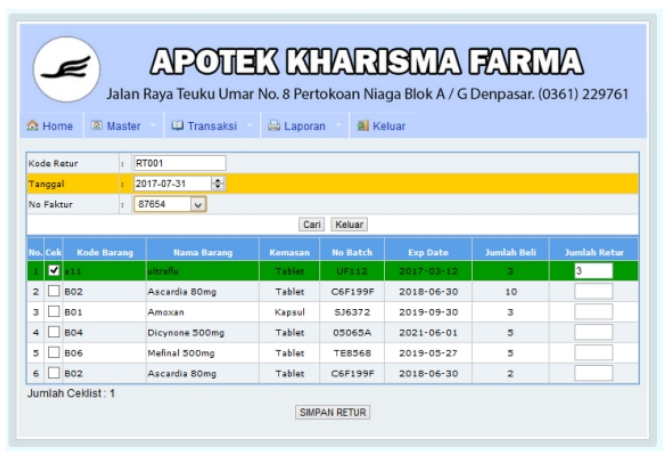

\section{Gambar 10 Menu Retur}

\section{Menu Laporan Data Barang}

Laporan barang berisi data - data barang secara detail, data dapat di filter sesuai dengan kode barang yang diinginkan. Baris yang berwarna kuning tersebut menandakan bahwa obat telah kadaluarsa dan akan diretur. Laporan data barang ini dapat dicetak dengan ektensi pdf.

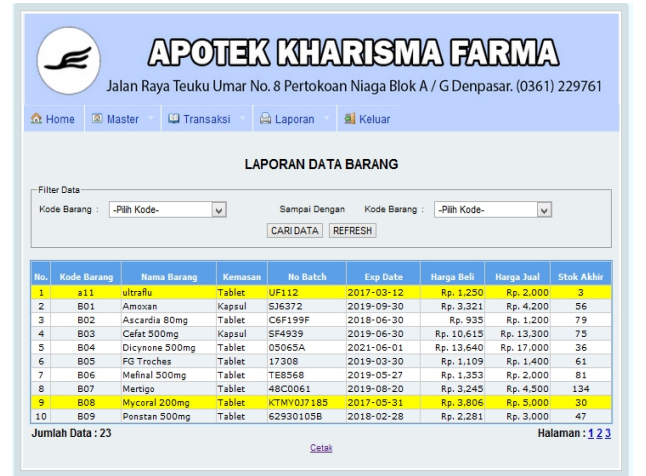

Gambar 11 Laporan Data Barang

\section{Menu Laporan Pembelian}

Laporan pembelian berisi transaksi pembelian obat dengan supplier secara detail, data laporan dapat di filter sesuai tanggal pembelian yang sudah ada dan dapat dicetak dengan ekstensi

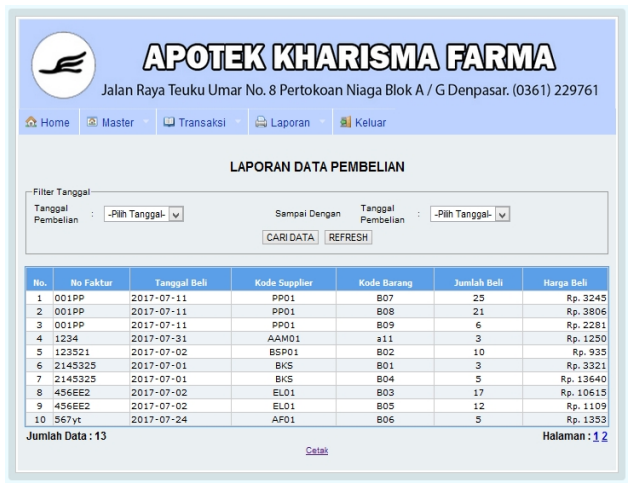




\section{Menu Laporan Penjualan}

Laporan penjualan berisi transaksi penjualan yang telah terjadi, data yang ada dapat di filter sesuai dengan tanggal transaksi yang ada, kemudian dapat dicetak.

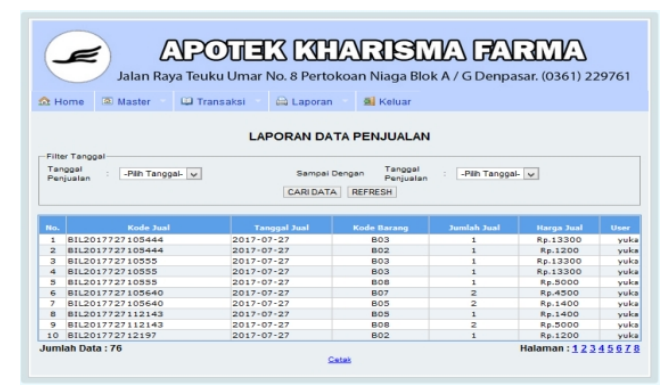

\section{Gambar 13 Menu Laporan Penjualan}

\section{Menu Stok Barang}

Laporan stok barang berisi data - data jumlah barang dari transaksi pembelian, penjualan dan retur terlihat baris yang berwarna merah adalah tanda jika stok barang tersebut sudah habis.

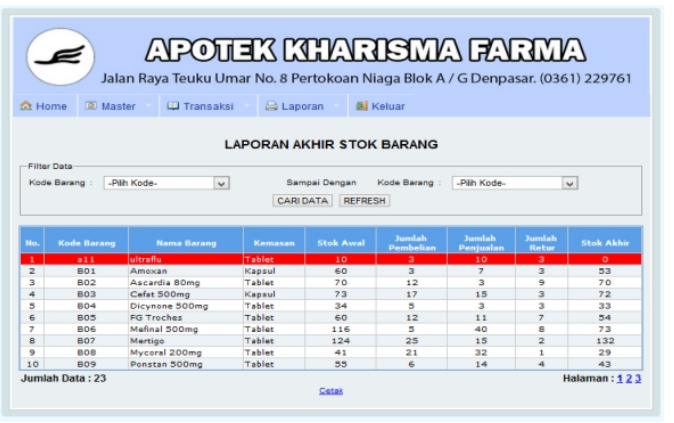

\section{Gambar 14. Menu Stok Barang}

\section{Menu Barang Laku - Tidak}

Laporan barang laku dan tidak merupakan laporan yang melaporkan setiap barang yang paling laku sampai tidak laku sehingga user dapat mengetahui barang yang paling laku terjual.

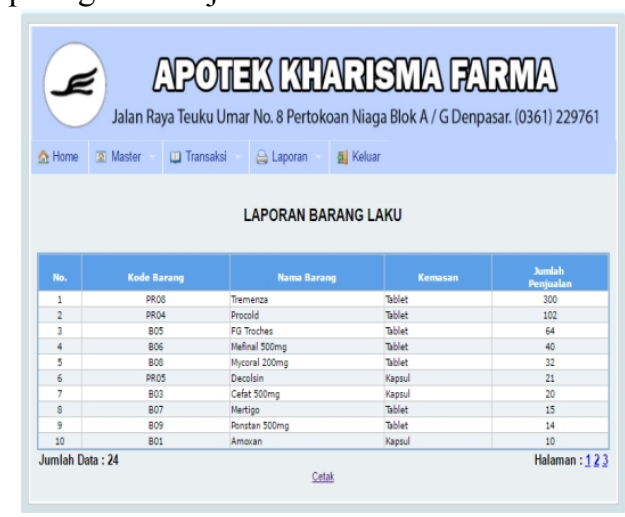

Gambar 15 Barang Laku - Tidak

\section{Menu Laporan Laba - Rugi}

Laporan laba dan rugi merupakan laporan yang melaporkan transaksi pembelian dan transaksi penjualan sehingga dapat terlihat keuntungan atau kerugian yang dialami dalam setiap bulannya.

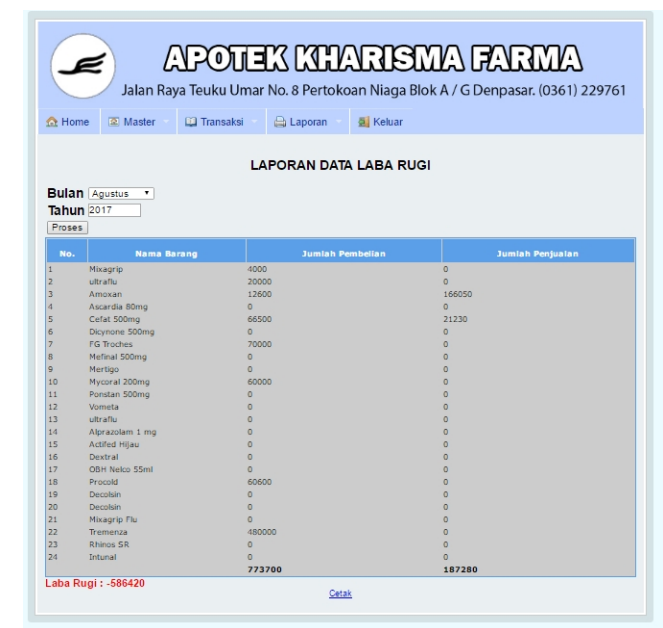

Gambar 16 Laporan Laba - Rugi

\section{Pengujian Blackbox}

Blackbox merupakan metode testing yang menggunakan kontrol struktur dari rancangan prosedural untuk melakukan testcase dan mengetahui internal dari website. Design test dijalankan pada semua internal dari website untuk memastikan semua beroperasi berdasarkan spesifikasi dan desain.

\section{KESIMPULAN}

Berdasarkan hasil penelitian mengenai perancangan sistem informasi dengan metode enterprise resource planning untuk manajemen dan inventori pada apotek kharisma farma denpasar dapat disimpulkan bahwa:

Aplikasi sistem informasi manajemen dan inventori apotek yang dirancang dapat menampilkan layanan pembelian, penjualan dan stok barang untuk mengurangi adanya penggandaan data dan kerugian

Perancangan yang dilakukan pada aplikasi menggunakan pengambilan keputusan mengenai barang yang sifatnya laku (fast moving) dan tidak laku (slow moving) juga mengenai retur barang sehingga dalam pembuatan laporan obat, laporan pembelian, laporan penjualan, laporan stok barang dan manajemen sistem lebih maksimal. 
Dengan adanya aplikasi ini laporan obat, laporan pembelian, laporan penjualan dan laporan stok barang dapat dilakukan dengan sederhana.

\section{DAFTAR PUSTAKA}

[1] Agus., 2011, Trik Kolaborasi Codeigniter dan JQuery, Lokomedia, Yogyakarta.

[2] Andri., Kristanto, 2003, Perancangan Sistem Informasi dan Aplikasinya, Andi, Yogyakarta.

[3] Dhewanto, W, Falahah., 2007, ERP

(Enterprise Resource Planning)

Menyelaraskan Teknologi Informasi

dengan Strategi Bisnis, Informatika, Bandung

[4] Kadir, Abdul., 2002, Dasar - Dasar

Pemrograman Web, Andi, Yogyakarta

[5] Sutanta, Edhy., 2003, Sistem Informasi

Manajemen, Graha Ilmu, Yogyakarta

[6] Wahyudi, Dwi., 2003, Membangun Situs

Menggunakan phpWebsite, PT Elex

Media, Jakarta 